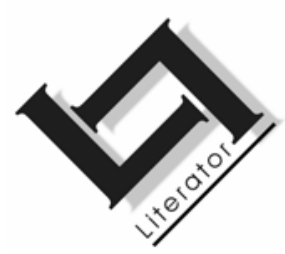

\title{
Skinder as gespreksgenre
}

\author{
G.S. (Truida) van der Merwe \\ Departement Afrikaans en Nederlands \\ Universiteit van Stellenbosch \\ MATIELAND \\ E-pos: gsvdm@sun.ac.za
}

\section{Abstract \\ Gossip as a discourse genre}

Gossip is one of the wide range of sub-categories of discourse genres in story-telling. It is one of the most common interactive forms of discourse in informal conversation, because it has its origin in the general inclination of man to show an intense interest in other people's activities. Although the development of gossip differs with regard to the subject of discussion, the context and situation in which it is produced as well as the persons participating, it is possible to distinguish definite universal features of gossip. This article deals with the most prominent characteristics of gossip. The focus falls on the structure, the gossiping process, the content, the pejorative, evaluating nature of it and the social aspects involved in gossiping. Special attention is paid to non-verbal elements, which are frequently used when people gossip. In spite of the negative connotations gossip has, it is very important in the establishment of social identities and relations. It should therefore not be neglected in the study of language.

\section{Opsomming}

\section{Skinder as gespreksgenre}

Skinder word as een van die wye verskeidenheid subkategorieë in die gespreksgenre van storievertelling beskou. Dit is een van die mees algemene, hoogs interaktiewe gespreksvorme in informele gesprekvoering, omdat dit spruit uit die neiging wat almal het, naamlik 'n intense belangstelling in iemand anders se doen en late. Hoewel elke skinderstorie op 'n unieke wyse verloop in ooreenstemming met die aard van die onderwerp, die konteks en die situasie waarin dit voorkom en die gespreksgenoot/-genote, kan daar ook definitiewe 
universele eienskappe by skinderstories onderskei word. In hierdie artikel word 'n poging aangewend om die opvallendste kenmerke van hierdie gespreksgenre aan te dui. Aspekte soos die bou van 'n skindergesprek, die verloop van die skinderproses, die inhoud, die pejoratiewe, evaluerende aard daarvan en die sosiale aspekte daaraan verbonde, word bespreek. Al word daar min positiewe konnotasies aan die begrip skinder geheg, speel dit 'n belangrike rol in die opbou en instandhouding van sosiale identiteite en verhoudings en verdien dit derhalwe die aandag van die taalwetenskaplike.

\section{Inleiding}

Hedendaagse navorsing oor die taalgebruik in gesprekke word veral vanuit twee perspektiewe gedoen. Die eerste is 'n sosiologiese perspektief, wat veral die benadering van die etnometodologie is. Belangrike verteenwoordigers van hierdie benadering is onder meer Garfinkel, Sacks, Schlegoff, Jefferson en Heritage. Die ondersoeke wat deur dié sosioloë verrig word, staan bekend as conversation analysis (gespreksontleding: GO) Die tweede dissipline waarbinne belangrike gespreksondersoek tans ingestel word, is die sosiolinguistiek. Onder die voorste navorsers in hierdie verband is Labov, Coulthard, Sinclair en Edmondson. Hulle ondersoeke word aangedui as discourse analysis (diskoersanalise: DA) (Haft-van Rees, 1989:11). Hierdie twee benaderingswyses verskil sowel in doelstellings as metodes en word vervolgens kortliks uiteengesit.

GO-navorsers gaan van die standpunt uit dat gesprekvoering een van die belangrikste sosiale aktiwiteite is in die totstandbrenging van die sosiale wêreld van die deelnemers. Hulle stel hulle derhalwe ten doel om 'n beskrywing te gee van die interaksionele prosedures wat deelnemers aan 'n gesprek volg by die produksie en interpretasie van gespreksbydraes. Die navorser beskryf in chronologiese volgorde die wyse waarop die interaksie tussen die gespreksdeelnemers ontwikkel. Daar word nie uitgegaan van aprioristiese teoretiese beskouings nie en slegs gewerk met empiriese gegewens wat verkry word uit klankopnames van gesprekke en presiese transkripsies daarvan (Haft-van Rees, 1989:11-12).

DA-navorsers, daarenteen, bekyk nie die gesprek uit die perspektief van die deelnemers nie. Hulle het ten doel om 'n beskrywing te gee van die strukturele beginsels waarop gesprekke berus. Vir dié doel word gesprekke geanaliseer en word gesoek na die reëls wat die opeenvolging van die taaluitings daarin kan verklaar. Veral die taalhandelingsteorie word as kader vir hierdie analise gebruik. Hul belangstelling is ook gerig op die verband tussen die vormkenmerke 
van taaluitinge en die taalhandelinge wat met die taaluitinge in die gesprek uitgevoer kan word (Haft-van Rees, 1989:12).

In hierdie artikel sal 'n geïntegreerde benadering gevolg word by die analise van skindergesprekke. Die gespreksgenre gaan bekyk word vanuit die perspektiewe van sowel die sosiologies-georiënteerde gespreksontleding as die linguisties-georiënteerde diskoersanalise, omdat albei 'n bydrae kan lewer tot beter insigte in die diskoersvorm skinder. Tans is die teoretisering van hierdie gespreksgenre nog in 'n embriostadium en is daar geen empiriese funderings vir die meeste van die bewerings oor skinder nie (Michelson \& Mouly, 2000:344). Taalwetenskaplikes besef egter terdeë dat 'n wetenskaplike ondersoek van hierdie "enjin wat die wêreld aan die gons hou, van direksievergaderings tot in die kombuis" belangrik is (Arbor, 1995:1). Die aard en die oogmerk van hierdie artikel is om ten opsigte van Afrikaans 'n bekendstelling van die onderwerp te wees. Die artikel moet dus nie beskou word as 'n verslag oor 'n diepgaande ondersoek van die skindergesprek in Afrikaanse konteks nie.

Die volgende bespreking bied 'n oorsig oor die vernaamste aspekte aangaande die skindergesprek wat navorsers al blootgelê het.

\section{Die begrip skinder}

Onder skinder word normaalweg verstaan dat twee of meer persone wat mekaar ken, op 'n agteraf wyse 'n informele, spontane gesprek voer oor 'n derde party wat nie teenwoordig of binne hoorafstand is nie (Allen \& Guy, 1974:247; Arbor, 1995:1; Bergmann, 1993;39-40). Meestal handel die gesprek oor die een of ander aspek van die derde party wat as afwykend van die standaarde en norme van die samelewing beskou word - kleredrag, haarstyl, persoonlike eienskappe, gedrag, familiebetrekkings, sosiale aktiwiteite en vermoëns. Dit is veral die negatiewe gedrag van persone wat die moeite werd geag word om oor te skinder, soos onbeskoftheid, rusies en buite-egtelike verhoudings (Allen \& Guy, 1974:248). Dit is soos volg deur Kowalski (2001:204) opgesom: "The juiciest things to gossip about are, after all, the things we most want to conceal, the things few people are likely to know directly." Die aard van die gesprek kan wissel. Volgens die menings van Allen en Guy (1974:247) en Arbor (1995:1) kan die skindergesprek ook byvoorbeeld redelik positief en komplimentêr van aard wees. Hulle meen dat die inligting wat uit skindergesprekke verkry word soms gunstig kan wees vir die betrokke derde party, al kom dit neer op 'n ligsinnige gebabbel, 'n ydele, nuttelose geklets oor bure, kollegas of 
ander bekendes se sake ter wille van die nuuswaardigheid daarvan en die bevrediging van nuuskierigheid. In die VSA geniet positive gossip tans groot belangstelling (Glaser, 2004:1-4). Hierdie konsep is nie algemeen bekend in Suid-Afrika nie. Afrikaanssprekendes is beter vertroud met 'n skinderkategorie wat Arbor (1995:2) die "klassieke" skinderkategorie noem. Dit word gekenmerk deur 'n opsetlike kwaadsprekery waarin vals, leuenagtige gerugte of negatiewe feite omtrent die derde party se karakter, uiterlike voorkoms of gedrag op 'n kwaadwillige, agteraf wyse versprei word. Meestal ook om daardie persoon/persone se goeie naam of eer te benadeel. Tipies vir so 'n gesprek is dat die sprekers 'n negatiewe, afkeurende gesindheid teenoor die derde party openbaar en 'n kritiese beoordeling en morele evaluasie uitspreek. Hierdie vorm van skindergesprek is soms gelykstaande aan laster (Odendal, 2000: 998; Labuschagne \& Eksteen, 1993 $\left.{ }^{8}: 780\right)$.

Die primêre vlak waarop geskinder word, is op die vlak van mondelinge kommunikasie. Moderne kommunikasie maak dit wel moontlik om ook via die media en ander elektroniese middele te skinder, maar dan is die risiko ten opsigte van laster groter. In hierdie verband sal slegs aandag geskenk word aan mondelinge skindergesprekke.

Net soos in die geval van enige ander informele gesprekvoering, is luisteraarsdeelname noodsaaklik om 'n skindergesprek op dreef te kry en vol te hou. Sowel die spreker as die luisteraar vervul 'n merkbare en onmiskenbare rol in die voortvloei van die gesprek. Dit is dus nodig dat die gespreksgenote mekaar redelik goed ken of dat daar 'n goeie verstandhouding tussen hulle ontwikkel het. Skindergesprekke word baie selde aangetref onder vreemdelinge of selfs blote kennisse wat nie noue kontak het nie. Dit is ook belangrik dat die sosiale waardes van die onderskeie deelnemers ooreenstem. Hulle moet eenderse houdings teenoor sekere aspekte binne hul spesifieke samelewing hê, of so nie, moet die een voorgee dat daar gelykvormigheid is met die waardes en houdings van die ander (Brown, 1995:219). Indien 'n derde party se optrede indruis teen die sosiale norme wat hulle as aanvaarbaar beskou, sal die skindergesprek juis floreer. Dit is egter nie noodwendig so dat alle betrokkenes in 'n geselskap waar geskinder word dit met mekaar eens is oor die skindernuus aangaande 'n beskinderde(s) nie. In so 'n geval is die kanse wel goed dat die oorheersende mening die andersdenkende(s) sal oortuig tot dieselfde standpunt of houding jeens die beskinderde (Kowalski, 2001:223). 
Om 'n geslaagde effek in 'n skindergesprek te verkry, is dit vir die spreker belangrik om die agtergrondkennis van die luisteraar(s), asook die sosiale konteks waarbinne die gesprek plaasvind, in ag te neem en te onthou dat die storie streng hiervolgens aangepas sal moet word (Brown, 1995:24). Om die aandag van die gespreksgenoot/-genote deurgaans te behou, moet die skinderstorie so boeiend en interessant moontlik oorgedra word. Hiervoor is daar, behalwe vir die gewone elemente, soos die regte woordkeuse, afwisselende sinstrukture, effektiewe gebruik van pousering en dies meer, ook ander nie-verbale elemente beskikbaar (kyk 6.2).

Die luisteraar, aan die ander kant, kan die gesprek goed laat vlot deur vir die spreker op die een of ander wyse 'n aanduiding van sy belangstelling te toon as aanmoediging om voort te gaan (Brown, 1995:26-27).

\section{Die skindergesprek as 'n onderskeibare gespreks- genre}

Die feit dat ' $n$ bepaalde tipe gesprek as 'n skindergesprek bestempel word, is 'n aanduiding dat dit 'n distinktiewe en karakteristieke struktuur het, wat dit onderskei van ander tipes gesprekvoering. Daar is wel enkele ander tipes gesprekke waarmee skinder ooreenkoms vertoon, soos die vertel van grappe - veral skunnige grappe in 'n klein kring. Indien hierdie grappe vertel word ten koste van of tot die nadeel van 'n persoon/persone, wat aan die kring bekend is, kan dit terselfdertyd as skinder bestempel word. Skinder stem ook in 'n mate ooreen met gewone alledaagse storievertelling in dié opsig dat dit dikwels narratief van aard is en gaan om die mededeling van iets of die skets van opeenvolgende gebeure. Daar is egter twee belangrike verskille tussen storievertel en skinder. Die eerste het betrekking op die fokus. In vertellings val die fokus meestal op die mededeling van ongewone ervarings en gebeure om die hoorder se ervaring en kennis van die wêreld te verbreed. In 'n skindergesprek, daarenteen, val die fokus meestal eerder op die negatiewe opinie en oordeel van die spreker(s) oor 'n afwesige derde party (Eggins \& Slade, 1997:276; Kowalski, 2001:210). Dit gaan hier om die verlustiging in situasies waarin die derde party se optrede sodanig is dat dit deur die samelewing as onaanvaarbare oortredings beskou word. Tweedens lê die verskil in die wyse van gesprekvoering. By gewone vertellings is luisteraarsdeelname nie ' $n$ noodsaaklikheid nie, maar by 'n suksesvolle skindergesprek wel. Hoewel die toon by skinder meestal deur die primêre spreker aangegee word, hang die sukses van die gesprek af van die 
wedersydse deelname van die betrokke partye, waar spreker- en hoorderrolle dikwels omgeruil word. By skinder is daar dus meer interaksie tussen die gespreksgenote as by die gewone vertelling. Gewoonlik is daar telkens beoordelende opmerkings of versoeke om meer detail vanaf die kant van die luisteraar(s). Hierdie blyke van belangstelling en terugvoer is van kardinale belang by die progressie van die gesprek. As die luisteraar(s) nie genoeë neem met wat gesê word nie, kan die gesprek doodloop of in 'n ander rigting gestuur word (Eggins \& Slade, 1997:274-276). Vertellings is nie in dieselfde mate afhanklik van so 'n voortstuwende krag van die kant van die luisteraar(s) nie.

Omdat daar definitiewe verskille is tussen skinder en ander gesprekstipes soos storievertel, kan die skindergesprek op sigself as 'n afsonderlike gespreksgenre beskou word.

Vervolgens sal die volgende aspekte in verband met skinder bespreek word:

- Skinder in sosiale verband;

- Die verloop van die tipiese skindergesprek;

- Die rol van nie-verbale kommunikatiewe elemente by skinder.

\section{Skinder in sosiale verband}

'n Hele aantal studies is al oor hierdie genre gedoen vanuit 'n sosiaal-teoretiese perspektief. Van die belangrikste bevindinge wat hieruit voortgevloei het, word vervolgens genoem.

In die samelewing bestaan daar 'n groot diskrepansie oor skinder. Enersyds is mense huiwerig om aan 'n skindergesprek deel te neem, omdat so 'n gesprek gediskrediteer en verdoem word as immoreel op grond daarvan dat dit karakterskendend en lasterlik kan wees. Andersyds bestaan daar 'n groot belangstelling om te hore te kom wat ook al van bekendes gesê word - om dié rede word daar gretig geskinder. Rondom hierdie diskrepansie word verskillende strategieë deur sprekers aangelê. Om te verbloem dat hulle besig is om te skinder, word die skindernuus meermale só aangebied dat dit nie maklik as sodanig herken kan word nie. Van die strategieë om die gevaar af te weer om as 'n skindertong gestigmatiseer te word, is om die skinder terug te voer na die oorspronklike bron en konteks waar dit ontstaan het. Sodoende word die skyn gewek dat die inligting wat verskaf word, toevallig ter sprake gekom het na aanleiding van iets wat vroeër in die gesprek 
genoem is en dat daar nie 'n beplande kwaadsprekery was nie (Bergman, 1993:77-78). Die gretigheid om meer te wete te kom van ander, dien weer as aansporing om stategieë te bedink om skinder te ontlok. So kan 'n brokkie skindernuus byvoorbeeld as lokaas aangebied word met die doel om nog meer inligting omtrent die beskinderde te verkry.

Een van die belangrike redes vir skinder is dus om inligting aangaande ander mense te verkry (Dunbar, 1996:9). Die inligting wat in skindergesprekke oorgedra word, is egter dikwels om velerlei redes nie waarheidsgetrou nie. Een daarvan is dat skindernuus meestal nie net by twee partye bly nie, maar in verdere skindergesprekke uitgedra word (Suls, 1977:164). In so 'n opeenvolgende mondelinge oordragsproses kan die inligting vele wysigings ondergaan. Dit kan ook doelbewus verdraai word om kwaadwillige redes of ter wille van sensasie. Dit is dus soms moeilik om te onderskei of iets soos "sy het haar pad boontoe oopgeslaap" 'n ongegronde gerug is, of 'n skinderstorie wat op die waarheid gegrond is (Rosnow, 1988:14). So iets is moeilik verifieerbaar, omdat die bron van inligting nie altyd deur die skinderaar vermeld word nie. In sommige gevalle beskou die spreker dit as onbelangrik, maar in ander gevalle word dit doelbewus verswyg uit vrees dat dit probleme kan oplewer. Die volgende tipiese aanloop vir 'n skindergesprek illustreer dié vrees: "Moenie vir my vra waar ek daaraan kom nie, maar het jy gehoor dat ...". Tog is die inligting wat in 'n skindergesprek oorgedra word, meestal nie te ver van die waarheid af nie. Navorsing wat deur Akanda en Odewale (1994:1-2) en Mishra (1990:217) gedoen is, toon dat die kernboodskap normaalweg behoue bly.

Nog 'n belangrike rede vir 'n skindergesprek is die behoefte van persone om sosiale verhoudings met bekendes, vriende of familie aan te knoop, te bevestig en te herbevestig (Rosnow, 1977:159). Dit kom daarop neer dat daar dikwels geskinder word met die doel om die aandag, belangstelling of simpatie van die gespreksgenoot op die spreker te fokus, om 'n impak te maak op die gespreksgenoot en om sosiaal deur daardie persoon aanvaar te word. Daar word dus geskinder ter wille van die bevordering van die eie sosiale aansien, status en mag. 'n Faktor wat 'n groot rol speel by die verstewiging van hegter bande tussen die gespreksgenote, is die konteks van privaatheid, intimiteit en geheimhouding waarin die skindergesprek gewoonlik plaasvind (Yerkovich, 1977:196). Verder stel 'n skindergesprek die deelnemers in staat om op grond van die inligting wat hulle daaruit verkry, sosiale vergelykings te tref en 
daarvolgens hul eie posisie, houding en vermoëns te evalueer ten opsigte van die besprokene(s). Die vergelykings kom meestal daarop neer dat die besprokene(s) baie slegter en swakker daaraan toe is as die skinderaars - dit is bedoel om die skinderaars goed te laat voel oor die gunstige uitkoms vir hulself (Michelson \& Mouly, 2000:341). Die moontlikheid bestaan dus dat die sprekers beter sal vertoon indien die derde party in 'n swak lig geplaas word. In sommige gevalle bestaan daar ook 'n sterk negatiewe gevoel teenoor die derde party en 'n sterk begeerte om die betrokke persoon/persone in 'n swak lig te plaas. 'n Verontregte houding kan byvoorbeeld tot 'n skindergesprek lei om wraak te neem op die derde party. So ook kan 'n gevoel van jaloesie of nydigheid tot gevolg hê dat daar geskinder word om die ander party te kritiseer of af te kraak.

Daar word ook dikwels om vermaaklikheidsredes geskinder. Dit kan byvoorbeeld groot opwinding en genot aan gespreksdeelnemers verskaf as die skinderstorie draai om 'n humoristiese insident waarby die besproke derde party betrokke was. In so 'n geval word daar ook dikwels vrye teuels aan die verbeelding gegee (Kowalski, 2001:218; Michelson \& Mouly, 2000:342). Ook in gevalle waar daar 'n gespanne atmosfeer heers, soos situasies waarin daar 'n kille verhouding tussen ' $n$ gesaghebbende en onderhoriges is, kan ' $n$ skinderstorie oor die maghebber die stresvlakke van die lydende party, soos werknemers of skoliere, verlaag.

Verskeie studies is al onderneem om te bepaal wie die eintlike betrokkenes by 'n skindergesprek is. In die verlede is die term skinder heel dikwels op 'n negatiewe wyse gebruik om spesifiek na die gesprekke tussen vroue te verwys. Dergelike stereotipering van vroue as skindertonge kan as 'n vorm van seksisme beskou word, aangesien navorsingsondersoeke bewys het dat skinder universeel is en ewe veel by albei geslagte en in alle ouderdomsgroepe voorkom (Allen \& Guy, 1974:247; Arbor, 1995:1; Bergmann, 1993:59).

Fox (2004:3) se navorsing het getoon dat vroue meer bedrewe as mans is om 'n skindergesprek vermaaklik te maak. Drie faktore dra hiertoe by: hoë, lewendige tone, baie besonderhede en entoesiastiese terugvoer. Mans se skindergesprekke handel meestal eerder oor hul eie sosiale betrekkinge. Fox het ook bevind dat baie mense genot daaruit put om 'n bietjie stout te wees en om die opwinding te ervaar wat die risiko verbonde aan 'n skindergesprek hulle verskaf. 
Parker en Teasley (Arbor, 1995:1) van die Universiteit van Michigan het tydens 'n kamp vir kinders tussen 9 en 12 jaar bevind dat die seuns en dogters ewe veel geskinder het; dat hulle gemiddeld 18 keer per uur geskinder het en dat dit ongeveer 50 persent van hul tyd in beslag geneem het. Daar is verder bepaal dat kinders meestal drie keer eerder oor hul eie geslag as oor die teenoorgestelde geslag skinder. Die verskil tussen die dogters en seuns is, dat die dogters meer geredelik oor seuns skinder van wie hulle hou. Hoe gewilder 'n seun, hoe groter is die kans dat die meisies oor hom sal skinder. Seuns aan die ander kant, praat min oor meisies van wie hulle hou. Dit is ook bevind dat seuns wat goed bevriend is, minder skinder as seuns wat mekaar nie so goed ken nie. Hierteenoor skinder dogters meer en beter, hoe nader bevriend hulle is (Arbor, 1995:1).

In 'n ander studie wat aan die Universiteit van Sydney in Australië en die Universiteit van Auckland in Nieu-Seeland aangepak is, is navorsing gedoen oor die rol van skinder in organisasies (Michelson \& Mouly, 2000:339). Daar is bevind dat skinder ' $n$ beduidende rol in die beroepswêreld speel, ten spyte van die universele standpunt dat betrokkenheid daarby onwenslik is. Verder is bepaal dat ouderdom, geslag, beroepstatus of -vlak nie belangrike faktore by skinder is nie.

In sosiale verband speel skinder dus 'n belangrike rol by die betrekkinge tussen mense. Aan die een kant kan dit teweegbring dat bande tussen die skinderaars gesmee of verstewig word. Aan die ander kant kan dit die beskinderde(s) se sosiale betrekkinge nadelig beïnvloed en groot onmin veroorsaak as die skinderaar uitgevind word.

\section{Die verloop van die tipiese skindergesprek}

Dit is moeilik om skindergesprekke te bestudeer as gevolg van die vertroulike aard daarvan. Dit is ook moeilik om veralgemenings te maak wat die verloop van 'n skindergesprek betref, omdat elke gesprek in 'n sekere sin uniek is weens die verskillende onderwerpe wat ter sprake kom en die wisselende kontekste en situasies waarbinne hulle voorkom. Tog kan sekere algemene eienskappe onderskei word, soos vervolgens kortliks aangetoon word.

'n Tipiese skindergesprek word meestal geopen deur 'n skindergambiet of ' $n$ duidelik identifiseerbare openingsfrase, soos een van die volgende:

Ek het nou die dag iets gehoor ... 
Julle gaan nie glo wat ...!

Raai net wat vertel iemand my nou die dag van ...

Hierna volg dikwels 'n versoek om geheimhouding, soos in Gesprek 1 (vgl. Addendum): "hou dit maar vir jouself"/"moet nou nie sê jy het dit by my gehoor nie".

Die gesprek kan nou verder op verskillende maniere verloop. Givón (1997:42-43) noem die moontlikheid dat die inleier min of meer 'n monoloog kan voer, deur byvoorbeeld ' $n$ vertelling te lewer. In ander tipe skindergesprekke kan die bydraes weer gemaak word deur verskillende gespreksgenote wat kennis dra van die onderwerp onder bespreking. Vir Eggins en Slade (1997:278) is 'n skindergesprek soos "lae" wat opgebou word of soos 'n heen-en-weer-spel tussen die gespreksgenote, omdat dit interaktief is. Soos geïllustreer in Gesprek 1, kan die verskillende gespreksgenote mekaar beïnvloed en kan die hoofverteller (Annette in hierdie geval) op verskillende maniere aangepor word om uit te brei, byvoorbeeld deur verbasing uit te druk, vrae te stel, te beaam wat gesê word en deur aan te vul. Soms kan dit wat die een sê, die ander herinner aan nog ' $n$ voorbeeld of insident. Daar is ook gevalle waar twee of meer persone as 't ware tegelyk verslag wil doen oor 'n insident. Hulle lewer dan 'n soort duet waarin hulle as 't ware gesamentlik die kommunikatiewe taak verrig. Omdat elkeen egter 'n unieke uitkyk op die lewe het, gebeur dit dikwels in sulke gevalle dat die twee sprekers die tema op verskillende maniere wil ontwikkel. Derhalwe onderbreek hulle mekaar en vul mekaar aan as daar, volgens die gevoel van die een of die ander, belangrike inligting uitgelaat word.

Wat die algemene boustene van enige skindergesprek betref, is daar volgens Eggins en Slade (1997:285) drie elemente wat ter sprake kom, naamlik die fokus op die beskinderde, die gedragstawing en die pejoratiewe evaluasie. Hierdie elemente kom altyd in 'n vaste volgorde voor.

\subsection{Fokus op die beskinderde}

In die eerste fase van die skindergesprek word die derde party, naamlik die party oor wie daar geskinder gaan word, bekendgestel. In hierdie fase word die solidariteit tussen die "ons" - die gespreksdeelnemers versus die afwesige derde party - bevestig. In Gesprek 1 word die derde party soos volg aangedui:

... wanneer laas het jy vir Christine en Johan hier oorkant gesien? 


\subsection{Gedragstawingsfase}

In hierdie fase verstrek die spreker(s) 'n bepaalde brokkie inligting en die gesprek word verder daaromheen opgebou met inligting en spekulasie wat die derde party meestal negatief uitbeeld. Dit berei die ander gespreksdeelnemer(s) voor om 'n standpunt in te neem en hul waardes ten opsigte hiervan te bepaal. Die spreker kry tydens hierdie fase ook die kans om aan die ander gespreksgenoot/-genote die idee te gee van wat nie as gewenste, toelaatbare en gepaste sosiale gedrag, optrede of waardes beskou kan word nie. In Gesprek 1 is die inligting wat verstrek word dat Christine en Johan uitmekaar is. Verder word besonderhede oor Christine se doen en late gegee wat haar in 'n swak lig stel. Daar word ook te kenne gegee dat die optredes waarvan hier sprake is nie strook met wat normaalweg as aanvaarbaar in die samelewing beskou word nie.

\subsection{Pejoratiewe evaluering}

Tydens hierdie fase word negatiewe uitspraak gelewer oor die derde party. Tipiese voorbeelde is kommentaar soos die volgende:

Kan jy nou dink dat 'n ouderling so kan optree?

of

Is dit nie 'n skande nie?

Nie alle skindergesprekke bereik hierdie fase nie. Indien dit egter wel so ver vorder, is dit in dié deel van die gesprek waar die gespreksgenote gewoonlik smaaklik kan voortborduur. Dit is ook gewoonlik hierdie pejoratiewe evaluasies wat die eintlike motivering agter die skindergesprek is en wat die teks vorentoe sal dryf of stuit. In Gesprek 1 word Christine deur Annette veroordeel as 'n vrou wat heeltemal oorboord gaan, omdat sy reeds in haar veertigs is en steeds soos 'n tiener wil lyk. Hierop volg nog verdere skindernuus, negatiewe spekulasies en snedige opmerkings.

Hierdie fases kan deur baie ander opsionele elemente aangevul word. Dit sal grotendeels afhang van die konteks en sosiale opset waarbinne die spesifieke gesprek plaasvind. Van hierdie opsionele elemente sluit byvoorbeeld die luisteraar se geskokte reaksie op die inleiding in en die soeke na verdere inligting en detail. In Gesprek 1 sê Susan, byvoorbeeld: "Is jy seker hulle is uitmekaar?"

Nog tipiese voorbeelde hiervan in skindergesprekke is die volgende: 
Wil jy vir my sê sy 't sowaar in die publiek, voor almal ... ?

En Toe? Het sy hom toe vertel van die ander ou?

Soms vorm 'n tematiese opsomming van die gebeurtenis(se) of gedrag die laaste fase van 'n skindergesprek, soos in Gesprek 1 gebeur:

Sulke dinge gebeur maar soms met mense van wie jy dit die minste verwag.

Hierdie opsomming neig gewoonlik om terug te verwys na inligting wat in die openingsfase van die gesprek genoem is (Eggins \& Slade, 1997:284-287).

Gesprek 2 (addendum) verloop effens anders, in dié opsig dat daar nie die tipiese inleiding is soos by die meeste skindergesprekke nie. Ilse lewer as 't ware 'n lang emosionele skindervertelling oor die slordige gewoontes van haar woonstelmaat. Daar is dus wel sprake van 'n lang gedragstawingsfase. Tussenin word sy deur haar aanhoorders onderbreek of aangevul deur vrae, opmerkings en verklarings. Pejoratiewe evaluering word ook gegee:

Ek sou dit nou nooit van haar gedink het nie! Dis dan nou 'n gewese Mej. Wes-Kaaplandfinalis wat so slordig is!

Verder word ook opsommings van die situasie gemaak:

Op die ou end voel jy soos die ou teef, want jy moet elke keer iets daaroor sê.

So nou moet jy maar mamma speel.

Ja, Nee, eintlik meer soos 'n bediende ...

\section{Die rol van nie-verbale kommunikatiewe elemente by 'n skindergesprek}

Afgesien van die verbale elemente wat in 'n skindergesprek gebruik word - soos in enige ander tipe gesprek - speel nie-verbale kommunikatiewe elemente ook dikwels 'n baie belangrike rol. Die milieu waarin die skindergesprek plaasvind en die vrees om afgeluister te word kan in sommige gevalle sodanige invloed op die aard van die gesprekvoering hê dat die verbale kommunikatiewe elemente tot 'n absolute minimum gereduseer word en swaar gesteun word op nie-verbale kommunikatiewe elemente. Twee van die nie-verbale kommunikatiewe elemente word vervolgens bespreek. 


\subsection{Sigbare buitetalige kommunikatiewe elemente}

Soos by ander gesprekke kan die deelnemers aan die skindergesprek van 'n wye reeks sigbare buitetalige elemente gebruik maak wanneer hulle skinder. Hierdie elemente sluit onder andere gesigsuitdrukkings, liggaamshouding en gebare in. Voorbeelde van hierdie tipe kommunikatiewe elemente is die knik van die kop, die knip van die oog of die optrek van die wenkbroue. Met behulp van hierdie sigbare buitetalige aksies kan daar by die skindergesprek bykomende inligting deurgegee word wat nie uit die woordelikse inhoud van die gesprek blyk nie. As die spreker byvoorbeeld op 'n bepaalde wyse die hand voor die mond hou, kan dit as teken dien dat dit wat gesê word 'n geheim is en nie algemeen rugbaar gemaak moet word nie. Die hoorder kan weer sy reaksie en houding laat blyk uit gesigsuitdrukkings, waaruit die spreker kan agterkom of sy uitlatings aanvaar word en of hy kan voortgaan met die proses.

\subsection{Nie-verbale hoorbare kommunikatiewe elemente}

In hierdie afdeling word tussen twee subtipes onderskei, naamlik spesiale tonale middele en gespreksgeluide.

\subsubsection{Spesiale tonale middele}

Hierdie middele behels die doelbewuste inspanning van stemkwaliteite om spesifieke semantiese effekte te verkry. Deur byvoorbeeld die wisseling van toonhoogtes en volume in die stemtoon, kan bykomende kwaliteite aan die gewone geuiterde woorde geheg word, om 'n bydrae te lewer tot die uitdrukking van die spreker se houding en emosie. Coulthard (1992:35) lewer verslag van 'n studie wat hieroor gemaak is en verklaar dat alle keuses van intonasievorme, willekeurig of onwillekeurig, altyd die een of ander interaksionele waarde het waaruit die spreker se ingesteldheid en gesindheid teenoor sy buitetalige wêreld blyk.

Wat spesifiek by die skindergenre ' $n$ algemene verskynsel ten opsigte van stemkwaliteitsvariasie blyk, is die wysiging van stemvolume. Wanneer 'n skinderstorie vertel word, is dit opvallend dat dit meestal eerder sagter en op 'n meer diskrete wyse as ander tipe gesprekke geuiter sal word. Dit hou verband met die aard daarvan - die geheimsinnigheid, taboe en stigma wat daaraan kleef, asook die gevaar dat die besprokene dit te hore kan kom.

Variasie in toonhoogte is ook vir die spreker belangrik om "sappigheid" en interessantheid aan die gesprek te verleen en die 
aandag van die gespreksgenoot/-genote te behou. By luisteraarsreaksies speel toonhoogte ook 'n belangrike rol. Uitings soos "Ja?" of "Wat vertel jy my nou?" word gewoonlik in 'n hoë stemregister uitgespreek met 'n styging aan die einde. Dit gee verbasing, nuuskierigheid en belangstelling te kenne, wat terselfdertyd as aansporing vir die verteller dien. Die manipulasie van stemkwaliteit kan dus 'n belangrike bydrae daartoe lewer om skindergesprekke goed op dreef te hou.

\subsubsection{Gespreksgeluide}

Gespreksgeluide is nie-grammatikale taaleenhede, waarvan sommiges ooreenkoms met leksikale eenhede vertoon, maar ander, soos fluite, aansienlik daarvan verskil. Hierdie eenhede word veral as luisteraarsinjale in skindergesprekke gebruik terwyl die spreker aan die woord is. Die luisteraar lewer hiermee kommentaar, sonder om 'n spreekbeurt waar te neem (Brown \& Yule, 1983:106).

Hierdie gepreksgeluide kan uit enkele vokale, konsonante, of spraakklanke in ongewone kombinasies bestaan. Voorbeelde hiervan is die volgende:

- "Um?" (met 'n styging in stemtoon aan die einde van die uiting) dit kan aandui dat die luisteraar volg en belangstel in dit wat vertel word.

- "Huh?" (ook met 'n styging na die einde) - dit kan byvoorbeeld as plaasvervanger van 'n sin soos "Wat vertel jy my dan nou?" optree.

- "Hah?" ('n diep inaseming, terwyl die stem opgaan) - dit kan die waarde hê van "Regtig? Ek glo dit nie!"

- "Ge" wat afkeur kan uitdruk.

- 'n Fluit van verbasing.

Nie-verbale kommunikatiewe gesprekselemente verleen dus dikwels 'n belangrike stukrag aan die skindergesprek.

\section{Slot}

Skindergesprekke is een van die mees algemene tipes informele gespreksvorme - so algemeen dat navorsers soos Fox (2004:2) reken dat dit twee-derdes van alle menslike kommunikasie uitmaak. Dit is dus logies dat die opbou en instandhouding van baie taalgebruikers se sosiale identiteite en verhoudings in ' $n$ hoë mate 
daarop gebaseer is (Eggins \& Slade, 1997:279). Uit die skinderpraatjies van 'n taalgemeenskap blyk wat die implisiete sosiale standaarde van die lede daarvan is. Allen en Guy (1974:248) som dit soos volg op:

The sanctions which make up the content of gossip are indicators of implicit social standards. If the support of social standards is one of the functions of gossip, then the identification of the standards which are implied by the sanctions would help to demonstrate that function.

Verdere studie oor die aard en funksie van hierdie hoogs interaktiewe gespreksgenre, teen die agtergrond van die SuidAfrikaanse konteks, is van die grootste belang. Dat skinder 'n onmiskenbare sosiale rol in die Suid-Afrikaanse samelewing speel, is gewis, maar baie aspekte van skinder met betrekking tot die SuidAfrikaanse sosiale struktuur moet nog ondersoek word. Daar kan byvoorbeeld, soos in die VSA, nagevors word in watter mate en op watter wyse mense oor selfone skindergesprekke voer (Fox, 2004:125 ) of daar kan bepaal word wat die rol van skinder in die sakewêreld is (Kurland \& Pelled, 2000:428-438).

\section{Addendum}

Skindergesprekke: Die onderstaande gesprekke is aan 50 tweedejaarstudente van die Departement Afrikaans en Nederlands aan die Universiteit van Stellenbosch voorgelê - hulle het bevestig dat dit tipiese skindergesprekke in die Afrikaanse kultuur is.

\section{Gesprek 1: $\quad$ Skinder tussen buurvroue}

Annette: Haai Susan, wanneer laas het jy vir Christine en Johan hier oorkant gesien?

Susan: Weet jy, nou dat jy vra ... ek het Johan nogal lanklaas gesien en Christine woerts en warts ook net hier in en uit. Hoekom vra jy?

Annette: Jong, hou dit maar vir jouself, maar hulle is glo uitmekaar.

Susan: Nooit, jy speel seker! Waar hoor jy dit?

Annette: Moet nou nie sê jy het dit by my gehoor nie, maar Nellie van hier annerkant het my nou die dag gesê dat Johan uitgetrek het en nou in 'n woonstel bly.

Susan: Dis snaaks, ek het dan net gister nog sy rooi Jetta hier sien inry. Is jy seker hulle is uitmekaar? 
Annette: Nellie sal nie sulke stories uit haar duim suig nie. Sy vertel my Christine het mos die begin van die jaar by die gym aangesluit en haar lewe draai nou net om haar lyf. Sy kan glo skaars wag dat Johan soggens werk toe ry, dan hop sy ook hier uit op 'n fiets met haar skrapse oefenklere aan en kom eers wie weet wanneer terug. En die lyfie word net al hoe dunner en die klere al hoe skrapser. Ek wonder of Christine ooit nog eet en of sy ooit vir Johan en die kinders kos maak. Sulke vroue wat in hul veertigs is en wil lyk soos tieners gaan mos heeltemal oorboord.

Susan: Die arme kinders. Hulle het mos twee kleinerige kindertjies - 'n seun en 'n dogter.

Annette: Nou dat ek daaraan dink. Hulle het mos so twee maande terug 'n groot partytjie daar by hulle huis gegee. Die motors het die hele wêreld vol gestaan. 'n Mens kon skaars straat af gery kry die aand. Ek het daarna gehoor dit was glo 'n Griekse partyjie. Bid jou dit aan! Almal het glo met lakens om hul lywe gedrapeer daar aangekom, maar het glo darem swemklere onder dit aangehad. En toe hang die mans in die swembad rond en die vrouens bedien hulle met drank en vrugte in die water. Vir my klink dit of drank en wellus daar hoogty gevier het. Alles was glo pikdonker net fakkels om die swembad en verder was die musiek so hard dat hoor en sien vergaan het. Ek is seker daar het daardie aand fout gekom, want buurvrou sê daar is later op mekaar gevloek en geskreeu.

Susan: Ja, ek onthou nou van dié partytjie.

Annette: Ja, jy weet, as mens jou te jonk vir jou jare probeer hou en daardie klas partytjies hou, broei daar altyd onheil uit. Ek het 'n vermoede dat Christine 'n ogie op iemand anders begin kry het en nie meer tevrede is met die stil en rustige Johan nie. En Johan was nooit 'n man wat nonsens verdra nie.

Susan: Ek sou nou nooit kon dink dat daar onenigheid tussen dié twee kon kom nie. Altyd so vriendelik gegroet as hulle laatmiddag hier verbystap.

Annette: Ja-nee, sulke dinge gebeur maar soms met mense van wie jy dit die minste verwag. Ek meen nou maar - hoeveel Sondae het hulle nie daar voor in die kerk gesit nie - so ewe prim en propper en kyk nou? 


\section{Gesprek 2: 'n Student skinder oor haar woonstelmaat se onnetheid}

Ilse: $\quad$ Kyk hoe mooi skoon (sarkasties) is dit hier - ek raak sommer venynig. (Almal lag.)

Ek's nou so vies. Dis net so lekker om weg te kom van die huis af. Marié moes nou al twee keer na hierdie storie luister, maar ek het nou vandag vir die 430ste keer hierdie jaar by die huis gekom wat Jackie "versuim" het om haar skottelgoed die afgelope 24 tot 48 uur te was. Dit staan soos die hele kombuis vol! Dit is soos ...

Ansie: Maar llse, sê jy dit vir haar? (Praat hard en hoog. Ontsteld.)

Ilse: $\quad$ Ek het die eerste 13 keer, Ansie, en dan is dit elke keer 'n onsmaaklikheid tussen ons. En dit is nie my werk om

Ansie: $\quad$ Maar vir wat moet jy dan nou alles ...

Ilse: $\quad$ Ek weet! (Hard en uiters ontsteld. Beduie met hande.) Maar soos ek netnou vir Jan verduidelik het: sy's te deur die mis - sy kom nie agter dis alles haar goed wat sy vuilmaak nie. Sy maak dit vuil, plak dit daar neer en loop aan. Dan, as ek haar nou aanvat, dan kan sy nou nie onthou dat dit alles hare is nie! Ten spyte van die feit dat ek nie eens daar was nie.

Ansie: $\quad$ Piet sê mos altyd dat sy nie juis 'n "rocket scientist" is nie.

Marié: Ja, miskien sukkel sy maar so bietjie om te vang dis haar skottelgoed waaroor jy jou so opwerk!

Ilse: $\quad$ En, soos, toe ek nou terugkom van die huis af, toe's daar nie 'n enkele skoon sokkie in my kas nie. Sy't als gedra, want sy was te lui om wasgoed te was. (Marié en Ansie maak ongelowige geluide.)

Ilse: $\quad$ Toe't sy alles gedra. Dit lê vuil onder haar bed saam met haar nat handoeke en my twee teelepels wat weg was.

Ansie: $\quad$ Ek sou dit nou nooit van haar gedink het nie! Dis dan nou 'n Mej.Wes-Kaapfinalis wat so slordig is!

Marié: Ja, hoor!

Ansie: Dit wys jou net!

Marié: Kyk, skottelgoed is een ding, maar sokkies is heeltemal anders! (Almal lag.) 
Ansie: En teelepels!

Marié: $\quad$ Onder die bed! (Almal lag.)

Ilse: $\quad$ En toe ek vandag daar kom, toe staan die botter al op die kassie van na vanoggend ontbyt al. En ek het drie-uur daar gekom. Toe's daai botter so waterig en dryf so in die bakkie rond. En ek het net laasweek met haar 'n "fight" gehad omdat sy altyd die botter en die maaskaas buite los. Kyk, sulke goed gaan by haar verby.

Marié: $\quad$ Maar llse, op die ou end voel jy soos die ou teef, want jy moet elke keer iets daaroor sê.

Ilse: Dis hoekom ek dit nie meer doen nie. Ek hou my mond en ...

Ansie: $\quad$ Maar dan raak jy heeltyd kwaad en sy ...

Ilse: $\quad$... voor haar, so: ek gooi dit in die wasbak en was dit en sy, dis nie asof sy dan sal sê 'Toemaar los, ek was dit' nie, want sy kom nie agter dat ...

Ansie: $\quad$ Maar hoe's dit by haar ...

Ilse: $\quad$... sy kom nie agter dat ek nie haar bediende is nie.

Ansie: Hoe's dit by haar huis?

Ilse: $\quad$ Haar ma werk, so hulle almal smyt hulle goed daar neer en sy kom doen dit maar in die aande as sy van die werk af kom.

Marié: $\quad$ Oe, dis lekker!

Ansie: $\quad$ So nou moet jy maar mamma speel.

Ilse: Ja. Nee, eintlik meer soos bediende! Ek kan dit nou nie meer vat nie. Sy irriteer my grensloos!

\section{Geraadpleegde bronne}

AKANDA, A. \& ODEWALE, F. 1994. Company rumour: The fact and fiction. Employment Bulletin and Industrial Relation Digest, 10(3):1-2.

ALLEN, D.E. \& GUY, R.F. 1974. Conversation analysis: The sociology of talk. The Hague/Paris: Mouton.

ARBOR, A. 1995. Boys gossip just as much as girls, study shows. Michigan : News and Information Services of The University of Michigan. http://www.umich.edu/ newsinfo/dsmail.html [6 Jun. 2003].

BERGMANN, J.R. 1993. Discreet indiscretions: The social organisation of gossip. New York: De Gruyter.

BROWN, G. 1995. Speakers, listeners and communication. Cambridge: Cambridge University Press. 
BROWN, G. \& YULE, G. 1983. Discourse analysis. Cambridge: Cambridge University Press.

COULTHARD, M, ed. 1992. Advances in spoken discourse analysis. London: Routledge.

DUNBAR, R. 1996. Grooming, gossip and the evolution of language. London: Faber \& Faber.

EGGINS, S. \& SLADE, D. 1997. Analysing casual conversation. London: Cassell.

FOX, K. 2004. Evolution, allienation and gossip: The role of mobile telecommunications in the 21st century. http://www.sirc.org/publik/ gossip.shtml [25 Oct. 2004].

GIVÓN, T. 1997. Conversation: Cognitive, communicative and social perspectives. Amsterdam/Philadelphia: John Benjamins.

GLASER, C. 2004. Positive gossip. Dallas Business Journal. http://dallas. bizjournals.com/dallas/stories/2004/10/11smallb3.html [21 Oct. 2004].

HAFT-VAN REES, M.A. 1989. Taalgebruik in gesprekken: Inleiding tot gespreksanalitisch onderzoek. Leiden: Nijhoff.

KOWALSKI, R.M., ed. 2001. Behaving badly: Aversive behaviors in interpersonal relationships. Washington: American Psychological Association.

KURLAND, N.B. \& PELLED, L.H. 2000. Passing the word: Toward a model of gossip and power in the workplace. Academy of Management Review, 25(2):428-438.

LABUSCHAGNE, F.J. \& EKSTEEN, L.C. $1993^{8}$. Verklarende Afrikaanse woordeboek. Pretoria: Van Schaik.

MICHELSON, G. \& MOULY, S. 2000. Rumour and gossip in organisations: A conceptual study. Management Decision, 38(5):339-346.

MISHRA, J. 1990. Managing the grapevine. Public Personnel Management, 19(2):213-228.

ODENDAL, F.F. 2000. Verklarende handwoordeboek van die Afrikaanse taal. Doornfontein: Perskor.

ROSNOW, R.L. 1977. Gossip and marketplace psychology. Journal of Communication, 27(1):158-163.

ROSNOW, R.L. 1988. Rumor as communication: A contextualist approach. Journal of Communication, 38(1):12-28.

SULS, J.M. 1977. Gossip as social comparison. Journal of Communication, 27(1):164-168.

YERKOVICH, S. 1977. Gossiping as a way of speaking. Journal of Communication, 27(1):192-196.

\section{Kernbegrippe:}

implisiete sosiale standaarde

nie-verbale kommunikatiewe elemente

pejoratiewe, evaluerende aard

skinder as gespreksgenre 


\section{Key concepts:}

gossip as discourse genre implicit social standards non-verbal communicative elements pejorative, evaluating nature 